\title{
Toxicological studies of Momordica charantia Linn Seed extracts in Male Mice
}

\author{
Estudios Toxicológicos de los Extractos de la Semilla de Momordica charantia Linn en Ratones \\ Macho
}

\author{
Sharanabasappa A. Patil \& Saraswati B. Patil
}

PATIL, S. A. \& PATIL, S. B. Toxicological studies of Momordica charantia Linn. Seed extracts in male mice. Int. J. Morphol., 29(4):1212-1218, 2011.

SUMMARY: An attempt to find out the male contraceptive molecule of plant origin, the extracts of seeds of Momordica charantia were tested in male mice. Petroleum ether, chloroform and ethanolic extracts of Momordica charantia were administered at the dose level of $25 \mathrm{mg} / 100 \mathrm{gm}$ body weight to the albino mice for 48 days intraperitoneally. All the extracts showed antispermatogenic effect as the number of spermatogonia, spermatocytes, spermatids and spermatozoa were decreased. The increase in the weight of epididymis, prostate gland, seminal vesicle and vas deferens indicates clearly the androgenic property of these extracts. After subjecting to preliminary phytochemical screening ethanol extract showed positive tests for alkaloids, flavonoids, glycosides, phenols, tannins, oils and fats. Out of the three extracts tested, the ethanol extract seems to be more potent in its contraceptive and androgenic activities.

KEY WORDS: Momordica charantia Linn; Toxicological; Androgenic; Testis; Spermatogenesis.

\section{INTRODUCTION}

Hormonally active chemicals that are capable of inducing adverse effects on reproduction and/or carcinogenesis in wildlife as well as human beings are featured as "endocrine disruptors" (ED). The National Academy of Science and the U.S. Environmental Protection Agency (EDSTAC) recommend various animal studies to clarify the characteristics of those hormonal active compounds. Although herbal medicines are effective in the treatment of various ailments very often these drugs are unscientifically exploited or improperly used.

Momordica charantia Linn. (Cucurbitaceae) grows in tropical areas, including countries like India, China, Japan, East Africa, and South America where it is used as food as well as the medicinal plant. It's a slender, climbing annual vine with long-stalked leaves and yellow, solitary male and female flowers borne in the leaf axils. The fruit looks like a warty gourd, usually oblong and resembling a small cucumber. The young fruit is emerald green, turning to orange-yellow when ripe. At maturity, the fruit splits into three irregular valves that curl backwards and release numerous reddish-brown seeds. Biological actions of various extracts of the plants or its constituents include antidiabetic
(Ahmed et al., 1998; Mastuda et al., 1999; Raza et al., 2000), anti ulcerogenic (Gürbüz et al., 2000), antimutagenic (Guevara et al., 1990), antioxidant (Scartezzini \& Speroni, 2000), anti-tumour (Lee-Huang et al., 1995a), immunomodulatory (Spreafico et al., 1983). Two proteins known as $\alpha$-and $\beta$ - monorcharin which are present in the seeds, fruits and leaves have shown to inhibit the human immune deficiency virus (HIV) in vitro (Zhang, 1992; LeeHuang et al., 1995b). Leaf extracts of bitter melon have demonstrated broad-spectrum antimicrobial activity. Various extracts of the leaves have demonstrated in vitro antibacterial activities against E. coli, Staphylococcus, Pseudomonas, Salmonella, Streptobacillus and Streptococcus. Further it is also reported that alcoholic extracts of whole plant of $M$. charantia cause infertility in dogs (Bhargava, 1988). Many in vivo clinical studies have demonstrated the relatively low toxicity of all parts of the bitter melon plant when ingested orally. However, toxicity and even death in laboratory animals has been reported when extracts are injected intravenously. Other studies have shown extracts of the fruit and leaf (ingested orally) to be safe during pregnancy. The seeds, however, have demonstrated the ability to induce abortions in rats and mice, and the root has been documented 
as a uterine stimulant in animals. The fruit and leaf of bitter melon have demonstrated an in vivo antifertility effect in female animals. Our earlier studies have reported the estrogenic and antiovulatory activities in female rats (Sharanabasappa \& Saraswati, 2001; Sharanabasappa et al., 2002). The M. charantia is known for a variety of biological actions no systematic investigation for its male reproductive activities and toxicological studies has been done. Therefore in the present investigation an attempt was made to assess the effect of various extracts of seeds of $M$. charantia on spermatogenesis, development of its accessory reproductive organs and their androgenic nature in male mice.

\section{MATERIAL AND METHOD}

Plant material and preparation of the extract. In the present study the seeds of Momordica charantia were collected from the fields of north Karnataka region in the months of November and December 2002. This plant was authenticated at the Department of Botany, Gulbarga University, Gulbarga, India (Voucher specimen No. HGUG905). Seeds were shade dried and powdered. 500g powder was subjected to soxhlet extraction successively and separately from nonpolar to polar solvents i.e. petroleum ether, chloroform and ethanol. The extracts were concentrated to dryness in a flash evaporator under reduced pressure and controlled temperature $\left(40-60^{\circ} \mathrm{C}\right)$. The petroleum ether extract yielded yellow greasy extract (140g), chloroform extract yielded light yellow extract $(10 \mathrm{~g})$ and ethanol extract yielded dark brown gummy extract $(10 \mathrm{~g})$. All the extracts were prepared in Tween-80 (1\%) suspended in distilled water for their complete dissolution.

Phytochemical study. The presence of various phytochemical constituents in petroleum ether, chloroform and ethanol extracts of $M$. charantia were carried out as described by Harborne (1973). Dragendroff's reagent was used for alkaloids, Libermann-Buchard reagent for steroids, Shinoda test for flavonoids, Keller-Kiliani test for glycosides and ferric chloride reagent for phenolic.

Animals. Twenty four colony bred male albino mice of Swiss strain 60-70 days old were used for the experiment (Animal ethics Reg.No. 34800/2001/CPAEA/ dated 1/9-08-2001). Six animals per group (4 groups) were housed in polycarbonate cages with soft rice husk bedding in a room controlled for 12-h light-dark cycle, ventilation (air exchange 18 time/ hour), temperature $\left(23-25^{\circ} \mathrm{C}\right)$ and relative humidity $(50-60 \%)$ during the study. The cages and husk bedding were exchanged twice in a week. The animal had given balanced food and water ad libitum.
Different extracts of $M$. charantia seeds were administered intraperitoneally for 48 days at the dose level of $25 \mathrm{mg} / 100 \mathrm{gm}$ body weight. Group I received $0.1 \mathrm{ml}$ Tween-80 (1\%) and served as control. Group II, III and IV received petroleum ether, chloroform and ethanol extracts in Tween-80 (1\%) respectively.

Histological studies. Animals were sacrificed by cervical dislocation on 49th day. Both the testis and accessory organs like caput epididymis, cauda epididymis, vas deferens seminal vesicle and prostate were dissected out, made free from surrounding fat and connective tissue and weighed to the nearest $\mathrm{mg}$. The organs from one side of each animal were fixed in Bouin's fluid and processed for histological studies. The diameter of testis and seminiferous tubule was made from randomly chosen 20 sections from each group appearing round at cross section by using ocular and stage micrometer. The spermatogenic elements like spermatogonia, spermatocytes and spermatids were counted. The sperm count from cauda epididymis done by using haemocytometer (Kempinas \& Lamano-Carvalho, 1987).

Biochemical studies. Organs (testis and epididymis) from other side were processed for biochemical estimations like protein (Lowry et al., 1951), glycogen (Caroll et al., 1956), cholesterol (Peters \& Vanslyke, 1946), acid phosphatase and alkaline phosphatase (Bessy et al., 1946).

Hematology studies. Total Red blood corpuscles (RBC) and white blood corpuscles (WBC) were assessed by cell counter method (haemocytometer) and hemoglobin content is assessed by using heamometer in control and extract treated animals.

Statistical analysis. All the values were statistically analysed and means of different groups were compared using Student's t-test (Snedecor \& Cochran, 1967). The values were judged as significant at $\mathrm{P}<0.01$ and $\mathrm{P}<0.001$.

\section{RESULTS}

The results of phytochemical screening of three extracts are shown in Table I. The petroleum ether extract showed positive tests for steroids, oils and fats. The chloroform extract showed the positive tests for steroids, alkaloids, oil and fats. The ethanol extract showed positive tests for alkaloids, flavonoids, glycosides, phenols, tannins, oils and fats.

Means of the initial (before treatment) and final (after treatment) body weights as well as the percentages of body 
weight changes relatively to the initial body weights of control and extracts treated mice are presented in Table II. The control, both the doses of petroleum ether and ethanol extract treated animals gained weights at the end of the experiment and appeared to be non-toxic as observed by survival outcome. There is no change in morphological and behavioral pattern. Whereas, both the doses of chloroform extract treated animals showed comparable body weight loss as compared to control ones and appeared to be presence of toxic compounds in the extract.

Petroleum ether, chloroform and ethanol extracts of $M$. charantia have decreased the weight, diameter of testis and also diameter of seminiferous tubule. The number of spermatogonia, spermatocytes, spermatids and cauda epididymal sperm count were decreased with administration of all the three extracts. However ethanol extract seems to be more potent as compared to petroleum ether and chloroform extracts (Table III, V). All the three extracts effectively increased the weight of cauda and caput epididymis, vas deferens, seminal vesicle and prostate gland (Table III).

Table I. Phytochemical analysis of different extracts of $M$. charantia seeds.

\begin{tabular}{lccc}
\hline Chemical Classes & $\begin{array}{c}\text { Petroleum } \\
\text { ether }\end{array}$ & $\begin{array}{c}\text { Chloroform } \\
\text { extract }\end{array}$ & $\begin{array}{c}\text { Ethanol } \\
\text { extract }\end{array}$ \\
\hline Steroids & + & + & - \\
Alkaloids & - & + & + \\
Flavonoides & - & - & + \\
Glycosides & - & - & + \\
Phenols and Tannins & - & - & + \\
Oil and fats & + & + & + \\
\hline
\end{tabular}

+ : Positive test, - : Negative test.
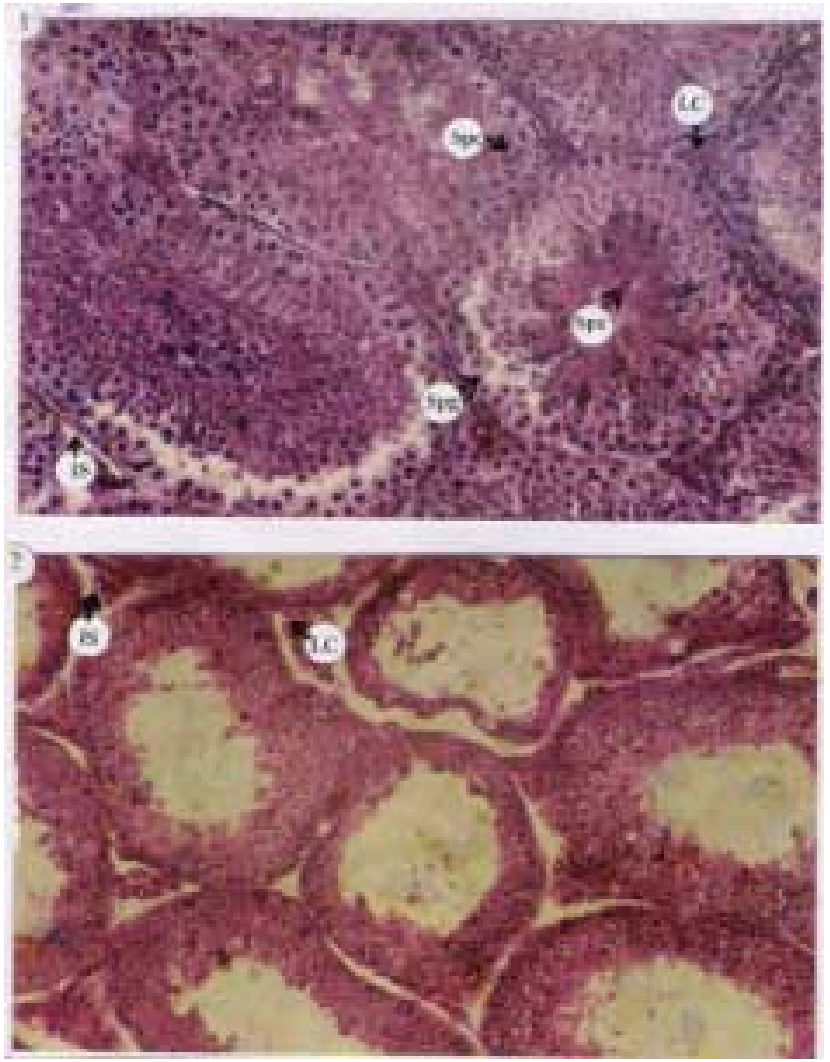

Fig.1. Cross section of testis of control mice showing spermatogonia (Spg), spermatocytes (Spc), spermatozoa (Spz) and healthy Leydig cells (LC).

Fig.2. Cross section of testis of mice administered with ethanol extract of Momordica charantia seeds showing absence of spermatids and spermatozoa enlarged interstitial space (IS) with Leydig cells (LC) which are decreased in size.

Table II. Body weight changes (mean \pm S.E of 6 mice) after treatment of $M$. charantia seed extracts for 7 days in male mice.

\begin{tabular}{lccccc}
\hline Treatment Group & $\begin{array}{c}\text { Dose }(\mathrm{mg} / 100 \mathrm{~g} \\
\text { body wt.) }\end{array}$ & $\begin{array}{c}\text { Initial body } \\
\text { weight }(\mathrm{g})\end{array}$ & $\begin{array}{c}\text { Final body } \\
\text { weight }(\mathrm{g})\end{array}$ & $\begin{array}{c}\text { Percentage } \\
\text { change }\end{array}$ & $\begin{array}{c}\text { Survival, } \\
\text { alive/ total }(\%)\end{array}$ \\
\hline Control -I & Tween-80 (1\%) & $30.00 \pm 0,81$ & $33.33 \pm 0.93$ & 13.30 & $6 / 6(100 \%)$ \\
Petroleum ether -II & 25 & $30.03 \pm 0.70$ & $33.20 \pm 0.82$ & 9.57 & $6 / 6(100 \%)$ \\
Chloroform -III & 25 & $30.30 \pm 0.84$ & $28.60 \pm 0.63$ & -5.61 & $6 / 6(100 \%)$ \\
Ethanol -IV & 25 & $31.50 \pm 0.80$ & $34.00 \pm 0.84$ & 7.93 & $6 / 6(100 \%)$
\end{tabular}

Table III. Weight changes (mean \pm S.E of 6 mice) in testis and accessory reproductive organs of mice treated with extracts of $M$. charantia seeds $(25 \mathrm{mg} / 100 \mathrm{~g}$ body weight for 48 days).

\begin{tabular}{lcccccc}
\hline Treatment Groups & Testis & Caput epididymis & Cauda epididymis & vas deferens & Seminal Vesicle & Prostate \\
\hline Control -I & $719.10 \pm 1.28$ & $142.90 \pm 0.45$ & $143.73 \pm 1.26$ & $94.33 \pm 1.19$ & $594.02 \pm 1.01$ & $80.54 \pm 1.25$ \\
Petroleum ether -II & $709.56 \pm 1.92$ & $148.00 \pm 1.70$ & $145.33 \pm 1.72$ & $101.33 \pm 1.52$ & $598.67 \pm 1.80$ & $116.67 \pm 1.21$ \\
Chloroform-III & $671.41 \pm 1.12^{*}$ & $189.71 \pm 1.26^{*}$ & $152.17 \pm 1.32^{*}$ & $97.51 \pm 1.17$ & $615.80 \pm 2.16^{*}$ & $82.35 \pm 2.14$ \\
Ethanol -IV & $625.87 \pm 1.60^{* *}$ & $236.04 \pm 2.78^{* *}$ & $209.00 \pm 1.25^{* *}$ & $116.00 \pm 1.26^{* *}$ & $649.26 \pm 1.23^{* *}$ & $134.87 \pm 1.3^{* *}$ \\
\hline
\end{tabular}

$* \mathrm{P}<0.01, * * \mathrm{P}<0.001$, when compared to control. 
Table IV. Biochemical Changes (mean \pm S.E of 6 mice) in the testis of mice treated with extracts of $M$. charantia seeds ( $25 \mathrm{mg} / 100 \mathrm{~g}$ body weight for 48 days).

\begin{tabular}{lccccc}
\hline $\begin{array}{l}\text { Treatment } \\
\text { Groups }\end{array}$ & Protein $(\mu \mathrm{g} / \mathrm{mg})$ & $\begin{array}{c}\text { Glycogen } \\
(\mu \mathrm{g} / \mathrm{mg})\end{array}$ & $\begin{array}{c}\text { Cholesterol } \\
(\mu \mathrm{g} / \mathrm{mg})\end{array}$ & $\begin{array}{c}\text { Acid phasphatase } \\
(\mu \mathrm{moles} \text { of p-nitro-phenol } \\
\text { relea sed/100mg/30 } \\
\text { minutes })\end{array}$ & $\begin{array}{c}\text { Alkaline } \\
\text { phasphatase }(\mu \mathrm{moles} \\
\text { of p-nitro-phenol } \\
\text { released/100mg/30 } \\
\text { minutes })\end{array}$ \\
\hline Control -I & $10.36 \pm 0.52$ & $1.15 \pm 0.04$ & $1.20 \pm 0.02$ & $28.76 \pm 1.07$ & $9.78 \pm 0.76$ \\
Petroleum ether - & $9.60 \pm 1.03$ & $0.98 \pm 0.03$ & $2.38 \pm 0.64 *$ & $26.45 \pm 1.12$ & $11.74 \pm 0.68$ \\
Chloroform -III & $8.03 \pm 0.01^{*}$ & $0.07 \pm 0.01 * *$ & $3.51 \pm 0.02 * *$ & $23.53 \pm 1.09 *$ & $14.34 \pm 1.34 * *$ \\
Ethanol -IV & $6.64 \pm 0.31^{* *}$ & $0.04 \pm 0.01 * *$ & $6.20 \pm 0.02 * *$ & $19.26 \pm 0.97 * *$ & $17.56 \pm 1.63 * *$ \\
\hline
\end{tabular}

$* \mathrm{P}<0.01, * * \mathrm{P}<0.001$, when compared to control.

Table V. Diameter of testis and seminiferous tubules in mice treated with $M$. charantia seed extracts $(25 \mathrm{mg} / 100 \mathrm{~g}$ body weight for 48 days).

\begin{tabular}{|c|c|c|c|c|c|c|}
\hline $\begin{array}{l}\text { Treatment } \\
\text { Groups }\end{array}$ & $\begin{array}{l}\text { Diameter of } \\
\text { testis }(\mu \mathrm{m})\end{array}$ & $\begin{array}{l}\text { Diameter of } \\
\text { seminiferous } \\
\text { tubule }(\mu \mathrm{m})\end{array}$ & Spermatog oni a & Speramtocytes & Spermatids & $\begin{array}{c}\text { Spermatozoa } \\
\text { (million / cauda } \\
\text { epididymis) }\end{array}$ \\
\hline Control -I & $304.25 \pm 9.13$ & $16.42 \pm 1.20$ & $85.00 \pm 3.23$ & $91.60 \pm 3.94$ & $135.6 \pm 4.89$ & $1.48 \pm 0.08$ \\
\hline Petroleum ether -II & $256.41 \pm 10.40$ & $13.64 \pm 0.72$ & $77.0 \pm 5.04$ & $72.00 \pm 9.35^{*}$ & $92.4 \pm 3.36^{* *}$ & $1.08 \pm 0.05$ \\
\hline Chloroform-III & $208.90 \pm 11.28^{*}$ & $11.04 \pm 6.38$ & $63.00 \pm 5.92^{*}$ & $53.40 \pm 1.69 * *$ & $60.2 \pm 3.19 * *$ & $0.87 \pm 0.06$ \\
\hline Ethanol -IV & $198.38 \pm 9.85^{*}$ & $9.82 \pm 0.21^{*}$ & $56.8 \pm 2.15^{* *}$ & $66.60 \pm 3.03 * *$ & $21.4 \pm 1.78 * *$ & $0.42 \pm 0.03 *$ \\
\hline
\end{tabular}

values are mean $\pm \mathrm{S}$.E of 6 mice. $* \mathrm{P}<0.01, * * \mathrm{P}<0.001$, when compared to control.

Table VI. Biochemical changes in the epididymis of mice treated with $M$. charantia seed extract (25mg/100g body weight for 48 days).

\begin{tabular}{lcccccc}
\hline Treatment & \multicolumn{2}{c}{ Protein $\mu \mathrm{g} / \mathrm{mg}$ tissue } & \multicolumn{2}{c}{ Glycogen $\mu \mathrm{g} / \mathrm{mg}$ tissue } & \multicolumn{2}{c}{ Cholesterol $\mu \mathrm{g} / \mathrm{mg}$ tissue } \\
\cline { 2 - 7 } Groups & Caput & Cauda & Caput & Cauda & Caput & Cauda \\
\hline Control -I & $0.27 \pm 0.01$ & $0.31 \pm 0.01$ & $0.20 \pm 0.007$ & $0.22 \pm 0.005$ & $0.06 \pm 0.002$ & $0.07 \pm 0.002$ \\
Petroleum ether -II & $0.92 \pm 0.01$ & $0.98 \pm 0.001^{* *}$ & $0.20 \pm 0.006$ & $0.21 \pm 0.008$ & $0.06 \pm 0.002$ & $0.10 \pm 0.004^{* *}$ \\
Chloroform-III & $1.07 \pm 0.01^{*}$ & $1.06 \pm 0.01^{* *}$ & $0.10 \pm 0.05^{* *}$ & $0.07 \pm 0.004^{* *}$ & $0.07 \pm 0.001^{*}$ & $0.18 \pm 0.002^{* *}$ \\
Ethanol -IV & $1.87 \pm 0.01^{* *}$ & $1.09 \pm 0.001^{* *}$ & $0.08 \pm 0.005^{* *}$ & $0.06 \pm 0.003^{* *}$ & $0.04 \pm 0.002^{* *}$ & $0.13 \pm 0.004^{* *}$ \\
\hline
\end{tabular}

values are mean \pm S.E of 6 mice. $* \mathrm{P}<0.01, * * \mathrm{P}<0.001$, when compared to control.

Decrease in protein, glycogen and acid phosphatase content but increase in cholesterol and alkaline phosphatase of the testis is observed (Table IV). The biochemical contents like protein, glycogen and cholesterol of caput and cauda epididymis show significant increase (Table VI).

There is no appreciable change in red blood corpuscles, white blood corpuscles and hemoglobin content is found in petroleum ether and ethanol extract administered animals when compared to control. In chloroform extract administered animal showed decrease in hemoglobin content observed.

\section{DISCUSSION}

The studies on a few plant extracts like Carica papaya (Lohiya et al., 2000, 2008), Morinda lucida (Raji et al., 2005), Colebrookia oppositifolia (Gupta et al., 2001), Melia azedarach (Sharanabasappa et al., 2003), Crotolaria juncea (Vijayakumar et al., 2004) have shown antispermatogenic effects in male rats and mice.

In the present study petroleum ether, chloroform and ethanol extracts of $M$. charantia have reduced the weight of 
testis. The observed reduction of the testicular weight may be due to the altered production of seminiferous tubular fluid (Ghosh et al., 1992). The protein content of any organ is directly proportional to the growth rate. The reduction in protein content of the testis in extract treated mice may also be another reason for reduction in the weight.

According to Lostroch (1963), FSH stimulates the development of spermatogonia and both FSH and LH are necessary for meiosis and development of spermatids. In the present study, the reduction in the number of spermatogenic elements viz. spermatogonia, spermatocytes and spermatids of the testis could be attributed to the decreased availability of pituitary FSH and LH due to the treatment of extracts. The degenerated Leydig cells observed in the testis of mice administered various extracts of $M$. charantia seeds also supports the above fact as the development and function of Leydig cells depend on pituitary LH ICSH (Hall, 1994).

The spermatozoa produced in the testis attain further development, motility and physiological maturation in the microenvironment of the epididymis (Sarkar, 1996). The decrease in the cauda epididymal sperm count may not only due to decrease in the testicular spermatogenic process, but also due to altered microenvironment of the epididymis.

It is well known documented that $\mathrm{LH}$ stimulates steroidogenesis. The conversion of cholesterol to pregnenolone in Leydig cells depends upon the availability of LH (Rommerts et al., 1974). The increased level of cholesterol in the testis of treated rats in the present study indicates inhibited synthesis of testosterone a potent androgen, in the testis.

Glycogen, a reserve carbohydrate found in Sertoli cells and spermatogonia in testis, serves as a source of glucose, which is an energy supplier to the tubular cells (Means \& Hall, 1968). Reduced glycogen content of the testis observed after the treatment of $M$. charantia seed extract in the present study may be due to impaired glycolysis (Mohri et al., 1975).
Similar observation has been made in the testis of dog treated with solusodine compound obtained from Sapindus trifoliatus (Dixit \& Gupta, 1982) and neem oil of Azadirachta indica (Kasturi et al., 2002).

Acid and alkaline phosphatases regulate the secretory activity of the testis and are present in seminiferous tubules and Leydig cells (Elkington \& Blackshaw, 1970). In the present study decrease in the acid phosphatase activity is seen. Such a decrease has been co-related with increased spermatogenic destruction, as a consequence of inadequate androgen supply within the testis (Blackshaw, 1973). Alkaline phosphatase is an enzyme, which acts as a marker for primordial germ cells (Mintz, 1957). An increased activity of this enzyme observed after treatment of extracts may indicate the predominance of germ cells, which are carried to the further spermatogenic process. An elevated alkaline phosphatase activity associated with testicular damage has been reported in rats with the treatment of crude extracts of Marsilea drummonodii (Bhardwaja \& Garg, 1984) and with the treatment of neem oil (Manoranjitham et al., 1993).

The increase in the weight of accessory sex organ such as epididymis, prostate, seminal vesicle and vas deferens after the administration of various extracts of $M$. charantia may be due to the androgenic activity of the plant extract. Therefore, it can be stated that though the extracts of $M$. charantia are antispermatogenic and they are potent androgenic in nature.

In conclusion, the antispermatogenic effects of $M$. charantia seeds seem to be mediated by disturbances in testicular somatic cell functions (Leydig and Sertoli cells) involved in the histophysiological events of spermatogenesis.

ACKNOWLEDGEMENT. Dr. Sharanabasappa is thankful to the Council of Scientific and Industrial Research-New Delhi INDIA, for their financial assistance provided through Research Associateship.

PATIL, S. A. \& PATIL, S. B. Estudios toxicológicos de los extractos de la semilla de Momordica charantia Linn. en ratones macho. Int. J. Morphol., 29(4):1212-1218, 2011.

RESUMEN: En un intento por descubrir la molécula de anticoncepción masculina de origen vegetal, fueron probados los extractos de semillas de Momordica charantia en ratones machos. Extractos de éter de petróleo, cloroformo y etanol de Momordica charantia fueron administrados en dosis de $25 \mathrm{mg} / 100 \mathrm{~g}$ de peso corporal a ratones albinos de 48 días por vía intraperitoneal. Todos los extractos mostraron un efecto antiespermatogénicos, con reducción del número de espermatogonias, espermatocitos, espermátidas y espermatozoides. El aumento de peso del epidídimo, próstata, vesículas seminales y conductos deferentes indica claramente la propiedad androgénica de estos extractos. Después de someter el extracto de etanol a la detección preliminar fitoquímica se observaron resultados positivos para alcaloides, flavonoides, glucósidos, fenoles, taninos, aceites y grasas. De los tres extractos probados, el extracto de etanol parece ser más potente en sus actividades de anticonceptivas y androgénicas.

PALABRAS CLAVE: Momordica charantia Linn; Toxicológico; Androgénicos; Testículo; Espermatogénesis. 


\section{REFERENCES}

Ahmed, I.; Adeghate, E.; Sharma, A. K.; Pallot, D. J. \& Singh, J. Effects of Momordica charantia fruit juice on islet morphology in the pancreas of the streptozotocin-diabetic rat. Diabetes Res. Clin. Pract., 40(3):145-51, 1998.

Bessy, O. A.; Lowry, O. H.; \& Brock, M. J. A method for rapid determination of acid and alkaline phosphatases with 5 cu.mm of serum. J. Biol. Chem., 164:321-9, 1946.

Bhardwaja, T. \& Garg, A. The antifertility effect of an Australian species of the aquatic fern Marsilea L. Indian Fern. J., 1:75-82, 1984.

Bhargava, S. K. Antifertility agents from plants. Fitoterapia, 59(3):163-77, 1988.

Blackshaw, A. W. Testicular enzymes and spermatogenesis. $J$. Reprod. Fertil. Suppl., 18:55-64, 1973.

Caroll, N. V.; Longley, R. W. \& Roe, J. H. The determination of glycogen in liver and muscle by use of anthrone reagent. J. Biol. Chem., 220(2):583-93, 1956.

Dixit, V. P. \& Gupta, R. S. Antispermatogenic and antiandrogenic activity of Sapindus trifoliatus fruit extract in intact and castrated male gerbils. Planta Med., 46(4):242-6, 1982.

Elkington, J. S. \& Blackshaw, A. W. The effects of testosterone, oestradiol and pregnant mare serum gonadotrophin on growth and enzyme activity in the rat testis. J. Reprod. Fertil., 23(1):110, 1970.

Ghosh, S.; Bartke, A.; Grasso, P.; Reichert, L. E. Jr. \& Russell, L. D. Structural manifestations of the rat Sertoli cell to hypophysectomy: a correlative morphometric and endocrine study. Endocrinology, 131(1):485-97, 1992.

Guevara, A. P.; Lim-Sylianco, C.; Dayrit, F. \& Finch, P. Antimutagens from Momordica charantia. Mutat. Res., 230(2):121-6, 1990.

Gupta, R. S.; Yadav, R. K.; Dixit, V. P. \& Dobhal, M. P. Antifertility studies of Colebrookia oppositifolia leaf extract in male rats with special reference to testicular cell population dynamics. Fitoterapia, 72(3):236-45, 2001.

Gürbüz, I.; Akyüz, C.; Yes,ilada, E. \& Sener, B. Anti-ulcerogenic effect of Momordica charantia $\mathrm{L}$. fruits on various ulcer models in rats. J. Ethnopharmacol., 71(1-2):77-82, 2000.

Hall, P. F. Testicular steroid synthesis: Organisation and regulation. In: Physiology of reproduction. Knobil, E. \& Neill, J. D. (Eds.). New York, Reven Press, 1994. pp.1335-62.

Harborne, J. B. Phytochemical methods. New York, Chapman and Hall Ltd., 1973. pp.37-214.
Kasturi, M.; Ahamed, R. N.; Pathan, K. M.; Manivannan, B. \& Aladakatti, R. H. Ultrastructural changes induced by leaves aof Azadirachta indica (Neem) in testis of albino rats. J. Basic Clin. Physiol. Pharmacol., 13(4):311-28, 2002.

Kempinas, W. G. \& Lamano-Carvalho, T. L. A method for estimating the concentration of spermatozoa in the rat cauda epididymis. Lab. Anim., 22:154-6, 1987.

Lee-Huang, S.; Huang, P. L.; Chen, H. C.; Huang, P. L.; Bourinbaiar, A.; Huang, H. I. \& Kung, H. F. Anti-HIV and anti-tumor activities of recombinant MAP30 from bitter melon. Gene, 161(2):151-6, 1995a.

Lee-Huang, S.; Huang, P. L.; Huang, P. L.; Bourinbaiar, A. S.; Chen, H. C. \& Kung, H. F. Inhibition of the integrase of human immuno deficiency virus (HIV) type 1 by anti-HIV plant proteins MAP 30 and GAP 31. Proc. Natl. Acad. Sci. USA, 92(19):8818-22, 1995b.

Lohiya, N. K.; Manivannan, B.; Goyal, S. \& Ansari, A. S. Sperm motility inhibitory effect of the benzene chromatographic fraction of the chloroform extract of the seeds of Carica papaya in langur monkey, Presbytis entellus entellus. Asian J. Androl., 10(2):298-306, 2008.

Lohiya, N. K.; Pathak, N.; Mishra, P. K. \& Manivannan, B. Contraceptive evaluation and toxicological study of aqueous extract of the seeds of Carica papaya in male rabbits. $J$. Ethnopharmacol., 70(1):17-27, 2000.

Lostroch, A. J. Effect of follicle stimulating hormone and interstitial cell stimulating hormone on spermatogenesis in Long-Evans rats hypophysectomised for six months. Acta Endocrinol. (Copenh), 43:592-600, 1963.

Lowry, O. H.; Roserbrough, N. J.; Farr, A. L. \& Randall, R. J. Protein measurement with the Folin phenol reagent. J. Biol. Chem., 193(1):265-75, 1951.

Manoranjitham, M. P.; Anandhi, A. P.; Sampathraj, R. \& Vanithakumari, C. Alteration in testicular histoarchitechture following neem oil adminsitration in albino rats. World Neem Conference, India. New Delhi, Neem and Environment ed. Oxford and IBH Publishing Co. Pvt. Ltd., 1993. pp.132-40.

Matsuda, H.; Li, Y.; Yamahara, J. \& Yoshikawa, M. Inhibition of gastric emptying by triterpene saponin, momordin Ic, in mice: roles of blood glucose, capsaicin-sensitive sensory nerves, and central nervous system. J. Pharmacol. Exp. Ther., 289(2):72934, 1999.

Means, A. R. \& Hall, P. F. Protein biosynthesis in the testis. I. Comparison between stimulation by FSH and glucose. Endocrinology, 82(3):597-602, 1968. 
Mintz, B. Embryological development of primordial germ cells in the mouse: Influence of a new mutation. J. Embryol. Exp. Morphol., 5:396-403, 1957.

Mohri, H.; Suter. D. A.; Brown-Woodman, P. D.; White, I. G. \& Ridley, D. D. Identification of the biochemical lesion produced by alpha-chlorohydrin in spermatozoa. Nature, 255(5503):757, 1975.

Peters, J. P. \& Vanslyke, D. D. Quantitative clinical chemistry. Baltimore, William and Wilkins, 1946. V. 1.

Raji, Y.; Akinsomisoye, O. S. \& Salman, T. M. Antispermatogenic activity of Morinda lucida extract in male rats. Asian J. Androl., 7(4):405-10, 2005.

Raza, H.; Ahmed, I.; John, A. \& Sharma, A. K. Modulation of xenobiotic metabolism and oxidative stress in chronic streptozotocin-induced diabetic rats fed with Momordica charantia fruit extract. J. Biochem. Mol. Toxicol., 14(3):1319, 2000 .

Rommerts, F. F.; Cooke, B. A. \& van der Molen, H. J. The role of cyclic AMP in the regulation of steroid biosynthesis in testis tissue. J. Steroid Biochem., 5(3):279-85, 1974.

Sarkar, H. B. D. Principles of vertebrate reproductive biology. Madras, Ganapathy Graphics, 1996. pp.130-215.

Scartezzini, P. \& Speroni, E. Review on some plants of Indian traditional medicine with antioxidant activity. $J$. Ethnopharmacol., 71(1-2):23-43, 2000.

Sharanabasappa, A. \& Saraswati, B. P. Effect of benzene extract of Momordica charantia seed extracts on reproductive activities in female albino rats. J. Med. Arom. Pl. Sci., 23:45-8, 2001.

Sharanabasappa, A.; Vijaykumar, B. \& Saraswati, B. P. Effect of Momordica charantia seed extracts on ovarian and uterine activities in albino rats. Pharm. Biol., 40(7):501-7, 2002.

Sharanbasappa, A. P.; Vijaykumar, B. M. \& Saraswati, B. P. Antispermatogenic and antiandrogenic activities of various extracts of Melia azedarach Linn. Seeds in albino rats. Orient. Pharm. Exp. Med., 3:133-140, 2003.

Snedecor, G. W. \& Cochran, W. G. Statistical methods. New Delhi, Oxford and IBH Publishing Co., 1967.

Spreafico, F.; Malfiore, C.; Moras, M. L.; Marmonti, L.; Filippeschi, S.; Barbieri, L.; Perocco, P. \& Stirpe, F. The immunomodulatory activity of the plant proteins Momordica charantia inhibitor and pokeweed antiviral protein. Int. J. Immunopharmacol., 5(4):335-43, 1983.

Vijaykumar, M. B.; Sangamma, I.; Sharanabasappa, A. \& Patil, S. B. Antispermatogenic and hormonal effects of Crotolaria juncea Linn. Seeds extracts in male mice. Asian J. Androl., 6(1):67-70, 2004.
Zhang, Q. C. Preliminary report on the use of Momordica charantia extract by HIV patients. J. Naturopath. Med., 3(1):65-9, 1992.

\author{
Correspondence to: \\ Sharanabasappa A. Patil \\ Reproductive Endocrinology Laboratory \\ Department of Studies in Zoology \\ Gulbarga University \\ Gulbarga -585 106 \\ INDIA
}

Email: sshanu@rediffmail.com

Received: 03-11-2010

Accepted: 15-06-2011 